\section{Physical activity, psychosocial and perceived environmental factors in adolescents from Northeast Brazil}

\author{
Atividade física e fatores psicossociais e ambientais \\ em adolescentes do Nordeste do Brasil
}

\author{
Actividad física, factores psicosociales y ambientales \\ en los adolescentes en el noreste de Brasil
}

1 Universidade Federal da Paraíba, João Pessoa, Brasil. 2 Universidade Federal do Paraná, Curitiba, Brasil.

3 Universidade Federal de

Pelotas, Pelotas, Brasil.

Correspondence

J. C. Farias Júnior

Departamento de Educação

Física, Universidade Federal

da Paraíba.

Campus I, João Pessoa, PB

88010-970, Brasil.

jcazuzajr@hotmail.com

\begin{abstract}
The aim of this study was to evaluate the association between levels of physical activity, psychosocial and perceived environmental factors in adolescents from Northeastern Brazil. A cross-sectional epidemiologic study was conducted with 2,859 adolescents enrolled in secondary schools ( $57.8 \%$ females; mean $=16.5$ years; $S D=1.2)$ in the city of João Pessoa, Paraíba State, Brazil. The following physical activity correlates were measured: attitude, self-efficacy, social support from friends and parents, and perceived environmental characteristics. Physical activity was measured using a questionnaire. Multivariable ordinal logistic regression with proportional odds model analysis showed that the following factors are positively related to physical activity levels in adolescents: attitude, self-efficacy, as well as social support from parents and friends. Physical activity intervention programs should increase self-efficacy and social support from parents and friends, as well as a positive attitude toward physical activity.
\end{abstract}

Motor Activity; Social Support; Adolescent
José Cazuza de Farias Júnior 1 Rodrigo Siqueira Reis 2 Pedro Curi Hallal 3

\section{Resumo}

Este estudo analisou a associação do nível de atividade física com fatores psicossociais e ambientais em adolescentes do Nordeste do Brasil. Estudo epidemiológico transversal desenvolvido com 2.859 adolescentes (57,8\% do sexo feminino, média de idade: 16,5 anos; $D P=1,2)$ no Município de João Pessoa, Paraíba, Brasil. Os seguintes fatores associados à atividade física foram mensurados: atitude, autoeficácia, apoio social dos pais e amigos e características do ambiente percebido. O nível de atividade física foi mensurado por questionário. Os resultados da análise multivariável por regressão logística ordinal, com modelo de odds proporcionais, identificaram os seguintes fatores positivamente associados ao nível de atividade física dos adolescentes: atitude, percepção de autoeficácia, apoio social dos pais e amigos. Programas de promoção da atividade física devem desenvolver ações para aumentar a autoeficácia dos adolescentes e o apoio social fornecido pelos pais e amigos, bem como desenvolver e reforçar atitudes positivas em relação à atividade física.

Atividade Motora; Apoio Social; Adolescente 


\section{Introduction}

Regular physical activity engaged in by adolescents has beneficial effects on cardiorespiratory fitness, muscle strength, bone density, obesity, blood pressure, lipoprotein levels, metabolic syndrome, and mental health 1,2. Furthermore, physical activity behaviors are usually maintained from adolescence to adulthood, that is, adolescents who are currently inactive tend to retain these behaviors as they grow older ${ }^{3}$. However, the prevalence of adolescents who do not perform enough physical activity to result in health benefits (for example, at least 60 minutes per day of moderate-to-vigorous physical activity 4 ) is unacceptably high 5 in a number of countries, including Brazil 6 .

Efforts to increase physical activity levels among young people have expanded 7,8. However, despite progress in evaluating the effectiveness of physical activity intervention programs, their effects are considered non-significant and much remains unknown about their long-term effectiveness 7,8 . The identification of factors that may influence physical activity levels in adolescents, particularly those that could be potentially modified, has been considered an essential requirement in developing effective intervention programs 9,10,11.

Physical activity in adolescents has been shown to be associated with factors such as demography, biology, psychology, behaviour, and socio-cultural and environmental factors, indicating complex and multidimensional behaviour 10,11,12. Thus, social-ecological models are considered the most suitable for studying correlates or determinants of physical activity, since they indicate that different factors (demographic, biological, psychological, behavioural, social and environmental) influence the physical activity of adolescents 11,13,14. The social-ecological model in the present study was conceptualised based on psychological (attitude and self-efficacy), social (social support from parents and friends), and environmental factors (characteristics of the neighbourhood where the adolescents lived) 14 . Previous studies have demonstrated that attitude, self-efficacy, social support from parents and friends and environmental characteristics are important factors associated with physical activity in adolescents 10,11,15. Few studies have analysed factors from different levels of analyses that may influence physical activity in this population, especially those described previously.

Moreover, most studies on the subject generally used poor methodology (the most common shortcomings were reduced age group with non-representative samples, lack of validity and reliable measures of both correlates or determinants and physical activity practice) 12 , and were conducted with North-American or European adolescents 10,15,16, limiting extrapolation of the results to low- and middle-income countries, due to their particular socioeconomic, cultural and environmental characteristics 10 . In the Lancet series on physical activity, Bauman et al. 10 emphasises that understanding the correlates and determinants of physical activity, especially in low- and middle-income countries, could reduce the effect of future inactivity epidemics and contribute to effective global prevention of non-communicable diseases. To address this research gap, this study examined the association of physical activity and psychosocial (attitude, self-efficacy, social support) and environmental characteristics (characteristics of the neighbourhood) factors in adolescents from Northeastern Brazil.

\section{Methods}

\section{Design and sampling}

This study is a cross-sectional epidemiological study, with a target population of both public and private secondary school students in the city of João Pessoa, capital of Paraíba State, in the Northeast of Brazil. João Pessoa has a hot, humid inter-tropical climate with a population of 723,515 inhabitants, $99.6 \%$ of whom are in urban areas, and medium human development index $($ HDI $=0.783)$. The study was approved by the Federal University of Paraíba Ethics Research Committee (n. 0062/2009). All adolescents aged under 18 who enrolled in this study were authorised to do so by their parents or guardians.

The following parameters were considered for sample size calculation: estimated prevalence of $50 \%$ ( $\geq 300$ minutes per week of physical activity 4); acceptable error of 3 percentage points; $95 \%$ confidence interval $(95 \% \mathrm{CI})$; design effect $=$ 2; $30 \%$ increase for possible losses and refusals, with a resulting sample of 2,686 students. Of the 3,220 adolescents answering the questionnaires, 361 were excluded (271 individuals aged $<14$ or $>$ 19; 65 who did not provide their age; 5 with some physical or mental limitation; and 25 who left several questions unanswered). The final sample comprised 2,859 adolescents aged 14 to 19. The sample had $80 \%$ power to detect as statistically significant odds ratios $\geq 1.40$ for female adolescents and 1.50 for male adolescents 17 .

The sample was selected by conglomerates in two phases (1st phase: schools; 2nd phase: classes). In the first phase, secondary schools were 
stratified into four municipal regions (north, south, east and west) and ordered, from the lowest to the highest, by number of students, separately for type (public and private). Next, 30 schools were systematically selected (16 public and 14 private), proportionally distributed according to their size (measured as number of students) and the four municipal regions. In the second phase, we randomly selected 135 secondary school classes stratified by school year (1st, $2^{\text {nd }}$, $3^{\text {rd }) ~ a n d ~ s c h o o l ~ s h i f t ~[d a y ~(m o r n i n g ~+~ a f t e r n o o n), ~}$ night]. This strategy produced a representative sample of high school students who were living in neighbourhoods with different physical (infrastructure) and socioeconomic characteristics. This is important for studies on factors associated with physical activity, especially those involving the environment (perceived characteristics of the neighbourhood where the adolescents lived).

\section{Data collection and measures}

Data collection took place between May and September 2009 by a trained team, composed of six Physical Education university students supervised by the head researcher. Questionnaires were filled out by the adolescents themselves in the classroom, according to instructions provided during the interviews.

The following data were collected: socio-demographic (gender, age, time spent living in the neighbourhood, economic class), physical activity and psychosocial and perceived environmental factors. The economic classes were based on Brazilian Economic Classification Criteria of the Brazilian Association of Research Companies (ABEP, acronym in Portuguese) 18. These criteria include a series of questions related to household items such as number of bathrooms, owning a radio, television, washing machine, car, employing a full-time housekeeper, and parents' schooling, classifying people into the following economic classes: A (wealthiest), B, C, D and E (poorest).

Physical activity was measured using a previously tested questionnaire, adapted from a Self-Administered Physical Activity Checklist (test-retest reliability - ICC $=0.88$; 95\%CI: 0.84 0.91 ; concurrent validity - comparing the results of four 24-hour physical activity recalls: Spearman's rho $=0.62 ; \mathrm{p}<0.01$; kappa $=0.59$ ) 19 . The adolescents reported the frequency (days/weeks) and duration (minutes per day) of the physical activity engaged in for at least 10 minutes during the week previous to the collection, considering a list of 24 moderate to vigorous activities. The adolescents were instructed to consider the physical activities in different contexts: leisure, travel, and at school, considering only real-time activities.
The level of physical activity was calculated as the sum of time spent in each activity multiplied by its corresponding frequency, resulting in a score in minutes per week. This score was categorised into four levels (ordinal outcome) as follows: 0 minutes per week, 10-149 minutes per week, 150-299 minutes per week and $\geq 300$ minutes per week. This categorisation was necessary for statistical analyses and allows separating adolescents into different levels of physical activity and not just into two groups: meets vs. does not meet physical activity recommendations.

The following psychosocial and perceived environmental factors were measured: psychosocial - attitude, self-efficacy, social support from parents and friends; perceived environmental factors - safe physical activities, accessibility and attractiveness of physical activity sites, infrastructure and general maintenance of the neighbourhood where the adolescents lived. The scales used to measure the psychosocial and perceived environmental factors are described in Table 1. Detailed information about the development and validation process of these scales are described in Farias Júnior et al. 20. Scores for each of the psychosocial and perceived environmental factors were determined from the sum of points attributed to each answer.

\section{Data analysis}

The chi-square test was used to compare proportions and the independent t-test to compare means by gender. All continuous variables exhibited normal distribution ( $\mathrm{p}<0.05)$. Ordinal logistic regression with a proportional odds model was used to analyse the association between physical activity level (ordinal outcome categorised into four levels: 0 minutes per week $=0 ; 10-149 \mathrm{~min}$ utes per week $=1$; 150-299 minutes per week $=2$; $\geq 300$ minutes per week $=3$ ), psychosocial factors (attitude, self-efficacy, social support from parents and friends) and perceived environmental characteristics (access and attractiveness of the physical activity sites, safety, and neighbourhood structure). For the purpose of analysis, tertiles were calculated for each of the factors, with the first tertiles representing the highest values for each psychosocial and environmental factor.

Ordinal logistic regression produces an odds ratio that estimates the chance of an increase in one unit of the dependent variable for each unit rise in the independent variable. The Brant test 17 was used to verify the premise of proportional odds ratios for each of the variables, both individually and in the final models. All the independent variables were considered to construct the multiple model, excluding those with $\mathrm{p}$-value 
Table 1

Description of scales used to measure psychosocial and perceived environmental factors related to the practice of physical activity in adolescents.

\begin{tabular}{|c|c|c|c|c|c|c|}
\hline $\begin{array}{l}\text { Psychosocial and } \\
\text { environmental factors }\end{array}$ & Items & Score & $\alpha$ & ICC & Questions & Scale \\
\hline \multicolumn{7}{|l|}{ Psychosocial factors } \\
\hline Attitude & 5 & $4-20$ & 0.76 & 0.89 & $\begin{array}{l}\text { In my opinion, practicing physical activity most days } \\
\text { of the week is... [safe-unsafe, fun-boring, important- } \\
\text { insignificant, healthy-harmful, good-bad] }\end{array}$ & $\begin{array}{l}\text { Semantic differential, with } 4 \\
\text { points, anchored with bipolar } \\
\text { adjectives }\end{array}$ \\
\hline Self-efficacy & 10 & $10-40$ & 0.81 & 0.78 & $\begin{array}{c}\text { I think I can practice physical activity most days } \\
\text { of the week even if I have many things to do [lack } \\
\text { of companion, lack of places to practice physical } \\
\text { activity...] }\end{array}$ & $\begin{array}{l}\text { Likert with } 4 \text { points, } 1 \text { "Strongly } \\
\text { disagree" to } 4 \text { "Strongly agree" }\end{array}$ \\
\hline $\begin{array}{l}\text { Social support form } \\
\text { parents }\end{array}$ & 6 & $6-24$ & 0.90 & 0.91 & $\begin{array}{c}\text { During a common week, how often do your PARENTS } \\
\text { stimulate [practice/watch/comment/talk] you to } \\
\text { practice physical activities? }\end{array}$ & Never, rarely, frequently, always \\
\hline $\begin{array}{l}\text { Social support from } \\
\text { friends }\end{array}$ & 6 & $6-24$ & 0.81 & 0.89 & $\begin{array}{c}\text { During a common week, how often do your FRIENDS } \\
\text { stimulate [practice/watch/comment/talk] you to } \\
\text { practice physical activities? }\end{array}$ & Never, rarely, frequently, always \\
\hline \multicolumn{7}{|l|}{ Environmental factors * } \\
\hline $\begin{array}{l}\text { Access and } \\
\text { attractiveness of } \\
\text { places to practice } \\
\text { physical activity }\end{array}$ & 7 & $7-28$ & 0.73 & 0.82 & $\begin{array}{l}\text { In the neighbourhood I live in there are bicycle paths } \\
\text { [places to practice physical activities, several places I } \\
\text { like to go ...] }\end{array}$ & $\begin{array}{l}\text { Likert with } 4 \text { points, } 1 \text { "Strongly } \\
\text { disagree" to } 4 \text { "Strongly agree" }\end{array}$ \\
\hline $\begin{array}{l}\text { Safety to practice } \\
\text { physical activity }\end{array}$ & 4 & $4-16$ & 0.69 & 0.67 & $\begin{array}{c}\text { In the neighbourhood I live in it is not safe to ride } \\
\text { bikes because of the heavy traffic [places to practice } \\
\text { physical activity are not safe, the neighbourhood is } \\
\text { violent...] }\end{array}$ & $\begin{array}{l}\text { Likert with } 4 \text { points, } 1 \text { "Strongly } \\
\text { disagree" to } 4 \text { "Strongly agree" }\end{array}$ \\
\hline $\begin{array}{l}\text { Structure and general } \\
\text { maintenance of the } \\
\text { neighborhood }\end{array}$ & 4 & $4-16$ & 0.70 & 0.75 & $\begin{array}{c}\text { In the neighbourhood I live in there are sidewalks } \\
\text { in most of the streets [sidewalks are narrow, with } \\
\text { obstacles, it is polluted] }\end{array}$ & $\begin{array}{l}\text { Likert with } 4 \text { points, } 1 \text { "Strongly } \\
\text { disagree" to } 4 \text { "Strongly agree" }\end{array}$ \\
\hline
\end{tabular}

$\alpha$ : Cronbach's alpha; ICC: intra-class correlation coefficient.

* To answer these questions, the adolescents were oriented to consider a distance up to 10 minutes from their homes.

$<0.20$, using backward selection. Variables with $\mathrm{p}<0.05$ were considered factors associated with physical activity. Age, economic class, parents' schooling and time living in the neighbourhood were treated as confounding variables. The analyses were stratified by sex, since the factors associated with physical activity differ between males and females. Statistical analyses were carried out using Stata 12 (Stata Corp., College Station, USA), taking into account the sampling strategy ("svy") and significance level (5\%).

\section{Results}

The final sample comprised 2,859 adolescents aged 14 to 19 (mean $=16.5$ years; $\mathrm{SD}=1.2 ; 57.8 \%$ female); $65.9 \%$ of males and $69.3 \%$ of females were between 14 and 16 years old, $53.2 \%$ be- longed to middle and low economic classes and approximately $50 \%$ were children of parents who completed, at least, secondary school (Table 2).

Approximately half of the adolescents fulfilled the recommended 300 minutes per week of physical activity (50.2\%; 95\%CI: 47.3-53.1). Males were more physically active than females (66.3 vs. $38.5 \%$; $p<0.001$; data not shown in tables). In relation to the psychosocial and perceived environmental factors, the females had lower average values for the safe physical activity score compared to the males $(\mathrm{p}<0.001)$. Other factors showed no significant difference between sexes (Table 2).

Tables 3 and 4 present the results for crude and adjusted ordinal logistic regression analysis. In crude analysis, the following variables (Table 3) were directly associated to the level of physical activity in males: attitude, self-efficacy, social 
Socio-demographic and psychosocial and perceived environmental characteristics related to the practice of physical activity in adolescents.

\begin{tabular}{|c|c|c|c|c|c|}
\hline \multirow[t]{2}{*}{ Characteristic } & \multicolumn{2}{|c|}{ Males $(n=1,206)$} & \multicolumn{2}{|c|}{ Females $(n=1,653)$} & \multirow[t]{2}{*}{$\mathrm{p}$-value } \\
\hline & $\%$ & $n$ & $\%$ & $\mathrm{n}$ & \\
\hline \multicolumn{6}{|l|}{ Socio-demographic } \\
\hline \multicolumn{6}{|l|}{ Age (years) } \\
\hline $14-16$ & 65.9 & 795 & 69.3 & 1,146 & $0.05 *$ \\
\hline $17-19$ & 34.1 & 411 & 30.7 & 507 & \\
\hline \multicolumn{6}{|l|}{ Father's schooling } \\
\hline Incomplete elementary & 26.3 & 309 & 35.2 & 563 & $<0.01$ * \\
\hline Complete elementary & 19.9 & 233 & 17.5 & 279 & \\
\hline Complete secondary & 34.3 & 402 & 30.7 & 491 & \\
\hline Complete college & 19.5 & 229 & 16.6 & 266 & \\
\hline \multicolumn{6}{|l|}{ Mother's schooling } \\
\hline Incomplete elementary & 25.9 & 309 & 32.8 & 538 & $<0.01$ * \\
\hline Complete elementary & 18.5 & 221 & 19.2 & 315 & \\
\hline Complete secondary & 33.4 & 399 & 30.6 & 502 & \\
\hline Complete college & 22.2 & 266 & 17.4 & 283 & \\
\hline \multicolumn{6}{|l|}{ Economic class } \\
\hline A (wealthiest) & 11.3 & 119 & 8.0 & 117 & $<0.01$ * \\
\hline B & 39.4 & 416 & 34.4 & 506 & \\
\hline C & 42.1 & 446 & 48.9 & 717 & \\
\hline$D, E$ (poorest) & 7.2 & 76 & 8.7 & 127 & \\
\hline Time living in the neighborhood (months) & & & & & $0.69 *$ \\
\hline$\leq 6$ & 4.0 & 45 & 4.8 & 76 & \\
\hline $7-12$ & 5.0 & 57 & 5.4 & 84 & \\
\hline $13-24$ & 5.7 & 64 & 5.9 & 93 & \\
\hline$>24$ & 85.3 & 965 & 83.9 & 1,316 & \\
\hline \multicolumn{6}{|l|}{ Physical activity } \\
\hline \multicolumn{6}{|l|}{ Level of physical activity (minutes/week) } \\
\hline 0 & 10.5 & 127 & 22.6 & 373 & $<0.01$ * \\
\hline $10-149$ & 9.8 & 117 & 20.5 & 338 & \\
\hline $150-299$ & 13.4 & 161 & 18.5 & 338 & \\
\hline$\geq 300$ & 66.3 & 800 & 38.5 & 636 & \\
\hline Physical activity correlates & $M$ & SD & M & SD & \\
\hline Attitude & 16.6 & 2.2 & 17.4 & 2.2 & 0.55 ** \\
\hline Self-efficacy & 27.6 & 6.6 & 27.4 & 6.6 & 0.27 *夫 \\
\hline Social support from parents & 12.7 & 4.2 & 11.6 & 4.2 & $0.29 * \star$ \\
\hline Social support form friends & 16.8 & 5.0 & 13.4 & 4.8 & 0.35 ** \\
\hline $\begin{array}{l}\text { Access and attractiveness of places to practice physical } \\
\text { activity }\end{array}$ & 18.6 & 4.7 & 17.9 & 5.0 & $0.20 * \star$ \\
\hline Structure and general maintenance of the neighbourhood & 11.3 & 2.9 & 11.2 & 2.9 & 0.54 ** \\
\hline Safety to practice physical activity & 11.3 & 3.2 & 11.1 & 3.2 & $<0.01 \star \star$ \\
\hline
\end{tabular}

M: mean; SD: standard deviation.

* Chi-square test of heterogeneity;

$\star \star$ Independent t-test.

support from friends and parents, access and attractiveness of physical activity sites. The same variables were identified in females (Table 4), with the addition of variable structure and general maintenance of the neighbourhood.
In adjusted analysis (Table 3 and 4), we observed that adolescents with more positive attitudes towards physical activity, more self-efficacy and social support from friends were more likely to be physically more active than those 
Ordinal logistic regression for psychosocial and perceived environmental factors and levels of physical activity in male adolescents.

\begin{tabular}{|c|c|c|c|c|}
\hline \multirow[t]{2}{*}{ Variables } & \multicolumn{2}{|c|}{ Unadjusted analysis } & \multicolumn{2}{|c|}{ Adjusted analysis * } \\
\hline & OR & $95 \% \mathrm{Cl}$ & OR & $95 \% \mathrm{Cl}$ \\
\hline \multicolumn{5}{|l|}{ Attitude } \\
\hline 1 st tertile $* \star$ & 1.00 & & 1.00 & \\
\hline 2nd tertile & 2.22 & $1.65 ; 2.99$ & 2.24 & $1.65 ; 3.03$ \\
\hline 3rd tertile $* \star \star$ & 2.56 & $1.92 ; 3.41$ & 2.60 & $1.94 ; 3.47$ \\
\hline \multicolumn{5}{|l|}{ Self-efficacy } \\
\hline 1 st tertile ** & 1.00 & & 1.00 & \\
\hline 2nd tertile & 1.32 & $0.99 ; 1.75$ & 1.24 & $0.92 ; 1.66$ \\
\hline 3rd tertile $* \star \star$ & 2.11 & $1.54 ; 2.88$ & 1.63 & $1.17 ; 2.27$ \\
\hline \multicolumn{5}{|l|}{ Social support from parents } \\
\hline 1 st tertile ** & 1.00 & & 1.00 & 1.00 \\
\hline 2nd tertile & 1.54 & $1.17 ; 2.03$ & 1.12 & $0.81 ; 1.55$ \\
\hline 3rd tertile ${ }^{\star \star \star}$ & 2.92 & $2.16 ; 3.93$ & 1.54 & $1.06 ; 2.24$ \\
\hline \multicolumn{5}{|l|}{ Social support from friends } \\
\hline 1 st tertile $* \star$ & 1.00 & & 1.00 & \\
\hline 2nd tertile & 1.92 & $2.21 ; 3.87$ & 2.02 & $1.46 ; 2.83$ \\
\hline 3rd tertile *** & 4.98 & $3.63 ; 6.84$ & 2.94 & $1.96 ; 4.39$ \\
\hline Access and attractiveness of places to practice physical activity & & & Excluded & \\
\hline 1 st tertile ** & 1.00 & & & \\
\hline 2nd tertile & 1.12 & $0.84 ; 1.49$ & & \\
\hline 3rd tertile $* \star \star$ & 1.59 & $1.18 ; 2.11$ & & \\
\hline Structure and general maintenance of the neighborhood & & & Excluded & \\
\hline 1 st tertile ** & 1.00 & & & \\
\hline 2nd tertile & 1.07 & $0.78 ; 1.47$ & & \\
\hline 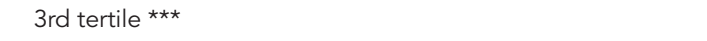 & 1.08 & $0.83 ; 1.41$ & & \\
\hline Safety to practice physical activity & & & Excluded & \\
\hline 1 st tertile $* \star$ & 1.00 & & & \\
\hline 2nd tertile & 1.02 & $0.77 ; 1.34$ & & \\
\hline 3rd tertile *** & 1.25 & $0.93 ; 1.69$ & & \\
\hline
\end{tabular}

95\% Cl: 95\% confidence interval; OR: odds ratio.

* Adjusted for: age, father's schooling, mother's schooling, economic class, time living in the neighborhood;

** Lowest levels;

$\star * \star$ Highest levels.

with lower scores. The supposition for proportional odds ratio was met by all variables in the final crude and adjusted models, with p-value > 0.05 (Brant test).

\section{Discussion}

The results of the present study showed that adolescents with positive attitudes towards physical activity, higher values of perceived self-efficacy and social support from both parents and friends are more likely to be physically active.
Strengths of the study include: the simultaneous analysis of multiple factors (individual, socio-cultural and perceived environmental factors), the inclusion of the main confounders in all analyses, the representative sample of adolescents in terms of sample size and selection, the satisfactory reliability and validity of the instruments used and their application by a trained team that followed the previously established protocol.

There was a positive association between attitude and physical activity level. In fact, as the attitude score increased, the chance of the a 
Ordinal logistic regression for psychosocial and perceived environmental factors and levels of physical activity in female adolescents.

\begin{tabular}{|c|c|c|c|c|}
\hline \multirow[t]{2}{*}{ Variables } & \multicolumn{2}{|c|}{ Unadjusted analysis } & \multicolumn{2}{|c|}{ Adjusted analysis * } \\
\hline & OR & $95 \% \mathrm{Cl}$ & OR & $95 \% \mathrm{Cl}$ \\
\hline \multicolumn{5}{|l|}{ Attitude } \\
\hline 1 st tertile $* \star$ & 1.00 & & 1.00 & \\
\hline 2nd tertile & 1.15 & $0.92 ; 1.44$ & 0.95 & $0.74 ; 1.22$ \\
\hline 3rd tertile $* \star \star$ & 1.92 & $1.54 ; 2.39$ & 1.53 & $1.20 ; 1.97$ \\
\hline \multicolumn{5}{|l|}{ Self-efficacy } \\
\hline 1 st tertile $* \star$ & 1.00 & & 1.00 & \\
\hline 2nd tertile & 0.99 & $0.80 ; 1.25$ & 0.98 & $0.76 ; 1.26$ \\
\hline 3rd tertile ${ }^{\star \star \star}$ & 1.39 & $1.12 ; 1.74$ & 1.30 & $1.01 ; 1.67$ \\
\hline \multicolumn{5}{|l|}{ Social support from parents } \\
\hline 1 st tertile ** & 1.00 & & 1.00 & \\
\hline 2nd tertile & 2.61 & $1.30 ; 2.00$ & 1.09 & $0.84 ; 1.44$ \\
\hline 3rd tertile *** & 2.69 & $2.13 ; 3.38$ & 1.46 & $1.08 ; 1.98$ \\
\hline \multicolumn{5}{|l|}{ Social support from friends } \\
\hline 1 st tertile ** & 1.00 & & & 1.00 \\
\hline 2nd tertile & 1.76 & $1.41 ; 2.17$ & 1.52 & $1.16 ; 2.00$ \\
\hline 3rd tertile ${ }^{* \star \star}$ & 3.13 & $2.49 ; 3.94$ & 2.65 & $1.94 ; 3.61$ \\
\hline Access and attractiveness of places to practice physical activity & & & Excluded & \\
\hline 1 st tertile $* \star$ & 1.00 & & & \\
\hline 2nd tertile & 1.14 & $0.91 ; 1.41$ & & \\
\hline 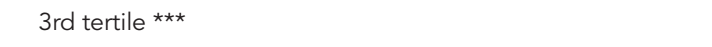 & 1.44 & $1.14 ; 1.80$ & & \\
\hline Structure and general maintenance of the neighborhood & & & Excluded & \\
\hline 1 st tertile ** & 1.00 & & & \\
\hline 2nd tertile & 1.09 & $0.86 ; 1.37$ & & \\
\hline 3 rd tertile $* \star \star$ & 1.25 & $1.02 ; 1.53$ & & \\
\hline Safety to practice physical activity & & & Excluded & \\
\hline 1 st tertile ** & 1.00 & & & \\
\hline 2nd tertile & 0.98 & $0.79 ; 1.23$ & & \\
\hline 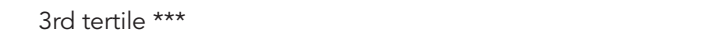 & 1.23 & $0.99 ; 1.53$ & & \\
\hline
\end{tabular}

95\% Cl: 95\% confidence interval; OR: odds ratio.

*Adjusted for: age, father's schooling, mother's schooling, economic class, time living in the neighborhood;

** Lowest levels;

*** Highest levels.

dolescents' reaching a category of higher physical activity level also rose for both males and females. A systematic review demonstrated that adolescents with more positive attitudes towards physical activity were physically more active 15 . Haerens et al. 21 observed a positive and significant relationship between attitude score and leisure physical activity levels in females, but not males, and Nelson et al. 22 found a significant association between negative attitudes and physical activity. However, Lee et al. 23 found no significant association between adolescents' attitude and physical activity level. This may be partially due to the oversimplified conceptualisation and measurement of attitudes and the tendency to focus only on the role of positive attitudes 22 . It is also important to consider that the influence of attitude on the physical activity levels of adolescents seems to vary with the type of attitude indicator (eg, instrumental, affective) and physical activity measured (global physical activity, structured physical activity, and active transport). Moreover, this association may be moderated by physical activity level and other variables such as sex and age.

There was a positive association between self-efficacy and physical activity level in adolescents. For instance, as the self-efficacy score 
increased, the likelihood of adolescents' reaching a category of higher physical activity level also rose. These results are similar to those reported in other studies $23,24,25,26$. The consistency of the relationship between physical activity and self-efficacy in a number of studies with adolescents suggests that the latter is an important predictor of physical activity level. Self-efficacy may influence motivational and self-regulatory processes, such as the type, magnitude and persistence of behaviour when facing obstacles 27 . Lubans et al. 28 found that self-efficacy was the most commonly assessed mediator and received the strongest support for mediating the relationship between theory-based interventions and physical activity in young people. Dishman et al. 29 observed that females who exhibited greater perception of social support during high school had less decline in physical activity, but only if they also had high self-efficacy. Furthermore, self-efficacy is a mediator of the relationship between the influence of social support and physical activity level in adolescents ${ }^{30}$. Adolescents with higher levels of social support from parents and friends tend to report higher perception of self-efficacy for overcoming barriers to physical activity. This construct has been shown to be associated with more adolescent participation in physical activity 30 .

There was a positive and significant relationship between social support from friends and parents and physical activity levels. Adolescents that received more social support from their parents were about $50 \%$ more likely to reach higher levels of physical activity than those receiving less social support. For social support from friends, the chance of an adolescent being physically more active was almost three times higher among those reporting more social support. These results are similar to those obtained by other studies, showing that adolescents who had more social support from their parents 23,25 and/or friends $24,23,30,31$ were physically more active. However, some studies identified no significant relationship between social support from parents 32 and/or friends 21,32 and physical activity level. Social support for physical activity can come in different forms, such as social integration or companions for physical activity; psychological or emotional support, provision of information on physical activity; and transport to the physical activity site 33 . Previous studies found that social support from parents and friends was inversely related to declines in physical activity in adolescents 29,33.

In relation to the perception of environmental characteristics, the access and attractiveness of the physical activity site score was directly associated to the physical activity levels of adoles- cents, in crude analysis, but was less significant ( $p>0.05$ ) in adjusted analysis. Other authors also found similar results to those obtained here 21,23. This variable significance loss occurred after adjusting for self-efficacy, suggesting that possible relationships between access and attractiveness of physical activity sites and physical activity levels may be mediated by self-efficacy. This might be a plausible explanation for studies that did not identify significant relationships between these variable 34,35 . Motl et al. 36 observed that relationships between sites and equipment used for physical activity and the physical activity levels of adolescents were totally mediated by self-efficacy. These results were similar to those obtained in other research using cross-sectional 37 and longitudinal data analysis 38 . It is also important to underscore that the relationship between environment characteristics and physical activity may be moderated by perceptions of self-efficacy. Deforche et al. 9 observed that self-efficacy appeared to moderate the link between active transportation and certain perceived physical environmental factors. Lower perceived safety and poorer access to recreational facilities was only associated with lower active transport in adolescents with lower self-efficacy $(\mathrm{p}<0.05)$.

The absence of a direct relationship between environmental characteristics and physical activity levels in the present investigation was also described in other studies $23,34,35$. However, some research has demonstrated that adolescents living in neighbourhoods with sites and equipment available for physical activity were physically more active 39,40 . Systematic reviews have demonstrated an inconsistent relationship between physical activity level and environment characteristics in adolescents 10,15,16. Most recently, Ding et al. 13 summarised findings from studies on the relationship between neighbourhood environment and physical activity in young people. Objectively measured, environmental attributes were much more consistently related to physical activity. There is a correlation between physical activity and residential density as well as land use mix; however, there is no correlation between physical activity and proximity to parks, recreational facilities and street connectivity. This may be explained by more accurate environment objective measures 13. Another aspect to consider is that environmental characteristics may differ in terms of degree of influence, depending on the outcome or measure of physical activity. Mota et al. ${ }^{41}$ showed that there are differences in the extent to which environmental characteristics can influence the participation of adolescents in structured and non-structured physical activities. 
The present study has the following limitations: since this was a cross-sectional study, it is not possible to establish cause-effect relationships. Measuring levels of physical activity using a questionnaire is always a limitation because of recall bias, reliability and validity of those being questioned. However, the reliability and validity (despite the limitation of the method of reference used in the present study) of the instrument used in the present study were satisfactory. Finally, perceptions of the environment were measured rather than actual characteristics; however, the measures were reliable and valid for the sample.

The present study shows that psychosocial factors such as attitude, self-efficacy and social support from parents and friends were positively associated with physical activity. These findings have very important implications for phys- ical activity promotion programmes. Craggs et al. 11 showed that higher levels of self-efficacy and social support were associated with smaller declines in physical activity compared to lower levels of self-efficacy and support for physical activity, indicating that these factors are also very important for maintaining physical activity levels during adolescence. Recently, priorities have been established to promote physical activity in Brazil, including the need for identifying physical activity correlates across different age groups 42 . The results of this study suggest that self-efficacy and social support from parents and friends are important components of strategies aimed at promoting physical activity in this group. Moreover, these strategies could produce better results if reinforcement of positive attitudes towards physical activity is encouraged.

\section{Resumen}

El objetivo de este estudio fue evaluar la asociación de la actividad física con los factores psicosociales y ambientales en los adolescentes en el noreste de Brasil. Se trata de un estudio epidemiológico transversal, realizado con 2.859 adolescentes (57,8\% mujeres, edad media: 16,5 años, $S D=1,2$ ) en la ciudad de João Pessoa, Paraíba, Brasil. Se midieron los siguientes factores asociados con la actividad física: actitud, autoeficacia, apoyo social de los padres y amigos, percepción de las características ambientales. El nivel de actividad física se midió mediante un cuestionario. Los resultados del análisis multivariante de regresión logística ordinal identificaron los siguientes factores asociados positivamente con los niveles de actividad física de los adolescentes: actitudes, percepciones de autoeficacia, apoyo social de los padres y amigos. Programas para promover la actividad física deben llevar consigo actividades para aumentar la autoeficacia y el apoyo social de los padres y amigos, así como desarrollar y fortalecer las actitudes positivas hacia la actividad física.

\section{Contributors}

J. C. Farias Júnior contributed to the data collection and analysis and to the writing of the paper. R. S. Reis contributed to the writing of the paper. P. C. Hallal contributed to the writing and review of the paper.

\section{Conflicts of interest}

The authors declare that there are no conflicts of interest.

\section{Acknowledgments}

We would like to thank Capes, for study and research grants, the Education Bureau of Paraíba State, and managers, teachers and students of the schools that took part in the study. 


\section{References}

1. Janssen I, LeBlanc AG. Systematic review of the health benefits of physical activity and fitness in school-aged children and youth. Int J Behav Nutr Phys Act 2010; 7:40.

2. Eime RM, Young JA, Harvey JT, Charity MJ, Payne WR. A systematic review of the psychological and social benefits of participation in sport for children and adolescents: informing development of a conceptual model of health through sport. Int J Behav Nutr Phys Act 2013; 10:98.

3. Telama R, Yang X, Leskinen E, Kankaanpää A, Hirvensalo M, Tammelin T, et al. Tracking of physical activity from early childhood through youth into adulthood. Med Sci Sports Exerc 2013; [Epub ahead of print].

4. World Health Organization. Global recommendations on physical activity for health. Geneva: World Health Organization; 2010.

5. Hallal PC, Andersen LB, Bull FC, Guthold R, Haskell W, Ekelund U. Global physical activity levels: surveillance progress, pitfalls, and prospects. Lancet 2012; 380:247-57

6. Barufaldi LA, Abreu GA, Coutinho ESF, Bloch KV. Meta-analysis of the prevalence of physical inactivity among Brazilian adolescents. Cad Saúde Pública 2012; 28:1019-32.

7. Sun C, Pezic A, Tikellis G, Ponsonby A-L, Wake M, Carlin JB, et al. Effects of school-based interventions for direct delivery of physical activity on fitness and cardiometabolic markers in children and adolescents: a systematic review of randomized controlled trials. Obes Rev 2013; 14:818-38.

8. Demetriou Y, Höner O. Physical activity interventions in the school setting: a systematic review. Psychol Sport Exerc 2012; 13:186-96.

9. Deforche B, van Dyck D, Verloigne M, De Bourdeaudhuij I. Perceived social and physical environmental correlates of physical activity in older adolescents and the moderating effect of self-efficacy. Prev Med 2010; 50 Suppl 1:S24-9.

10. Bauman AD, Reis RS, Sallis JF, Wells JC, Loos RJF, Martin BW. Correlates of physical activity: why are some people physically active and others not? Lancet 2012; 380:258-71.

11. Craggs C, Corder K, van Sluijs EMF, Griffin SJ. Determinants of change in physical activity in children and adolescents: a systematic review. Am J Prev Med 2011; 40:645-58.

12. Uijtdewilligen L, Nauta J, Singh AS, van Mechelen W, Twisk JWR, van der Horst K, et al. Determinants of physical activity and sedentary behaviour in young people: a review and quality synthesis of prospective studies. Br J Sports Med 2011; 45: 896-905.

13. Ding D, Sallis JF, Kerr J, Lee S, Rosenberg DE. Neighborhood environment and physical activity among youth: a review. Am J Prev Med 2011; 41:442-55.

14. Sallis JF, Cervero RB, Ascher W, Henderson KA, Kraft MK, Kerr J. An ecological approach to creating active living communities. Annu Rev Public Health 2006; 27:297-322.
15. van der Horst K, Paw MJCA, Twisk JWR, van Mechelen W. A brief review on correlates of physical activity and sedentariness in youth. Med Sci Sports Exerc 2007; 39:1241-50.

16. Ferreira I, van der Horst K, Wendel-Vos W, Kremers S, van Lenthe FJ, Brug J. Environmental correlates of physical activity in youth - a review and update. Obes Rev 2007; 8:129-54.

17. Abreu MNS, Siqueira AL, Caiaffa WT. Ordinal logistic regression in epidemiological studies. Rev Saúde Pública 2009; 43:183-94.

18. Associação Brasileira de Empresas de Pesquisa. Critério de classificação econômica Brasil. http:// www.abep.org (accessed on 26/Nov/2009).

19. Farias Júnior JC, Lopes AS, Mota J, Santos MP, Ribeiro JC, Hallal PC. Validity and reproducibility of a physical activity questionnaire for adolescents: adapting the Self-Administered Physical Activity Checklist. Rev Bras Epidemiol 2012; 15:198-210.

20. Farias Júnior JC, Lopes AS, Reis RS, Nascimento JV, Borgatto AF, Hallal PC. Development and validation of a questionnaire measuring factors associated with physical activity in adolescents. Rev Bras Saúde Matern Infant 2011; 11:301-12.

21. Haerens L, Craeynest M, Deforche B, Maes L, Cardon G, De Bourdeaudhuij I. The contribution of home, neighbourhood and school environmental factors in explaining physical activity among adolescents. J Environ Public Health 2009; 2009:320372.

22. Nelson TD, Benson ER, Jensen CD. Negative attitudes toward physical activity: measurement and role in predicting physical activity levels among preadolescents. J Pediatr Psychol 2010; 35:89-98.

23. Lee KS, Loprinzi PD, Trost SG. Determinants of physical activity in Singaporean adolescents. Int J Behav Med 2009; 17:279-86.

24. Bergh IH, Grydeland M, Bjelland M, Lien N, Andersen LF, Klepp KI, et al. Personal and socialenvironmental correlates of objectively measured physical activity in Norwegian pre-adolescent children. Scand J Med Sci Sports 2011; 21:e315-24.

25. Baskin ML, Herpreet T, Affuso O, Gary LC, LaGory M, Hwang S-S. Predictors of moderate-to-vigorous physical activity (MVPA) in African American Young adolescents. Ann Behav Med 2013; 45 Suppl 1:S142-50.

26. Taymoori P, Rhodes E, Berry TR. Application of a social cognitve model in explaining physical activity female adolescents. Health Educ Res 2010; 25:257-67.

27. Bandura A. Health promotion by social cognitive means. Health Educ Behav 2004; 31:143-64.

28. Lubans DR, Foster C, Biddle SJH. A review of mediators of behavior in interventions to promote physical activity among children and adolescents. Prev Med 2008; 47:463-70.

29. Dishman RK, Saunders RP, Motl RW, Dowda M, Pate RR. Self-efficacy moderates the relation between declines in physical activity activity and perceived social support in high school girls. J Pediatr Psychol 2009; 34:441-51. 
30. Heitzler CD, Lytle LA, Erickson DJ, Barr-Anderson D, Sirad JR, Story M. Evaluation a model of youth physical activity. Am J Health Behav 2010; 34: 593-606.

31. Fermino RC, RechI CR, HinoI AAF, Añez CRR, Reis RS. Atividade física e fatores associados em adolescentes do ensino médio de Curitiba, Brasil. Rev Saúde Pública 2010; 44:986-95.

32. McMinn AM, van Sluijs EMF, Wedderkopp N, Froberg K, Griffin SJ. Sociocultural correlates of physical activity in children and adolescents: findings from the danish arm of the european youth study. Pediatr Exerc Sci 2008; 20:319-32.

33. Dowda M, Dishman RK, Pfeiffer KA, Pate RR. Family support for physical activity in girls from 8th to 12th grade in south Carolina. Prev Med 2007; 44:153-9.

34. Autran RG, Ramos E, Pina MF, Santos MP. A associação entre a proximidade a equipamentos desportivos e a prática de atividade desportiva em adolescentes de 13 anos de idade do Município do Porto, Portugal. Cad Saúde Pública 2012; 28 : 549-58.

35. Perry CK, Saelens BE, Thompson B. Intrapersonal, behavioral, and environmental factors associated with meeting recommended physical activity among rural Latino youth. Pediatr Exerc Sci 2011; 23:521-36.

36. Motl RW, Dishman RK, Ward DS, Saunders RP, Dowda M, Felton G, et al. Perceived physical environment and physical activity across one year among adolescent girls: self-efficacy as a possible mediator? J Adolesc Health 2005; 37:403-8.
37. Bruijn G-J, Kremers SPJ, Lensvelt-Mulders G, Vries $\mathrm{H}$, van Mechelen W, Brug J. Modeling individual and physical environmental factors with adolescent physical activity. Am J Prev Med 2006; 30: 507-12.

38. Motl RW, Dishman RK, Saunders RP, Dowda M, Pate RR. Perceptions of physical and social environmental variables and self-efficacy as correlates of self-reported physical activity among adolescent girls. J Pediatr Psychol 2007; 32:6-12.

39. Pate RR, Colabianchi N, Porter D, Almeida MJ, Lobelo F, Dowda M. Physical activity and neighborhood resources in high school girls. Am J Prev Med 2008; 34:413-9.

40. Tucker P, Irwin JD, Gilliland J, He M, Larsen K, Hess P. Environmental influences on physical activity levels in youth. Health Place 2009; 15:357-63.

41. Mota JC, Almeida M, Santos R, Ribeiro JC, Santos MP. Association of perceived environmental characteristics and participation in organized and non-organized physical activities of adolescents. Pediatr Exerc Sci 2009; 21:233-9.

42. Reis RS, Kelly CM, Parra DC, Barros M, Gomes G, Malta D, et al. Developing a research agenda for promoting physical activity in Brazil through environmental and policy change. Rev Panam Salud Pública 2012; 32:93-100.

Submitted on $24 / \mathrm{Jan} / 2013$

Final version resubmitted on 21/Oct/2013

Approved on 14/Nov/2013 